\title{
ユーラパラメータの近似による $H_{\infty}$ 補償器の低次元化 ${ }^{\dagger}$
}

\author{
渡 辺 隆 男* ・安田 恵一郎* ・横 山隆 一*
}

\author{
A Reduction Method of $H_{\infty}$ Controller Based on Truncation of Youla Parameter
}

\author{
Takao Watanabe*, Keiichiro Yasuda* and Ryuichi Yokoyama*
}

\begin{abstract}
In this paper, a reduction problem of $H_{\infty}$ controllers is considered. The problem treated here is that of truncating high order $H_{\infty}$ controllers which are complicated by high order free parameters. This problem sometimes appears when a numerical approach is used for $H_{\infty}$ control problems. The $H_{\infty}$ controller is truncated by approximating a free parameter which is high order solution of the Model Matching Problem using the balanced realization approximation technique. This method preserves internal stability of closed loop systems and the domain in which closed loop poles locate. A sufficient condition for preserving an $H_{\infty}$-norm constraint of the closed loop system in which a high order controller is approximated by low order one is derived. Thus, in this reduction method closed loop properties are taken into account, i.e. the internal stability and the domain in which all closed loop poles locate are preserved.
\end{abstract}

Key Words : model reduction, $H_{\infty}$ control, balanced realization approximation, bilinear transformation

\section{1.はじめに}

$H_{\infty}$ 制御問題は, ユーラパラメトリゼーション $(\mathrm{YJB})$ により $H_{\infty}$ ノルムでの仕様を満たす安定かつプロパーな 有理関数を求めるモデルマッチング問題 $(\mathrm{MMP})$ に帰着 される. MMP を解く一つの解法として近年, Boydらの アプローチ1)が注目されている.このアプローチでは, 最 適化手法を用いて $H_{\infty}$ ノルムでの仕様を満足するように MMP のフリーパラメータを最適化している.このアプ ローチの特徵の一つは, 解析的に解くことの困難な多数 の仕様を満たす補償器を数值的手法によって求めること を可能にしている点にある，たとえば，ロバスト安定条 件に加え，フリーパラメータの自由度を用いて閉ループ 系の極指定などを行いながら MMP 解くことにより， 閉ループ系の時間領域における特性を考慮した $H_{\infty}$ 補償 器を求めることが可能である.しかしながら本アプロー チでは, 求められるフリーパラメータの次数が高次元と なり, その結果, 補償器の次数が増大することに問題点

†第 23 回制御理論シンポジウムで発表 $(1994 \cdot 5)$

* 東京都立大学工学部 八王子市南大沢 1-1

* Dept. of Electrical Engineering, Tokyo Metropolitan University, Hachioji

(Received July 12, 1994)

(Revised November 8, 1994)
がある2).したがって,このような高次元の $H_{\infty}$ 補償器を, 設計された閉ループ特性をできるだけ保ちつつ低次元化 することは重要な課題である.

そこで本論文では, 高次元で求められた MMP の解 (以下ではユーラパラメータとする)を低次元化すること により, $H_{\infty}$ 補償器の次数を間接的に低次元化する $H_{\infty}$ 補償器低次元化手法を提案する. 低次元化手法は, まず はじめに平衡実現近似手法を用いる. 平衡実現近似手法 は, モデルの漸近安定性を保存し, 入出力特性を保存し やすい近似手法である。 また，平衡実現近似手法を用い た場合, 元のシステムモデルのハンケル特異值を用いる ことによって, 近似誤差の上限を求めることが可能であ る.これらのことにより, 閉ループ系の内部安定性が保 存され, さらに閉ループ系の伝達関数の $H_{\infty}$ ノルム条件 を容易に調べることが可能である. しかしながら, 平衡 実現近似手法はモデルの極配置を一般に保存しないた め, 平衡実現近似手法を用いてユーラパラメータを近似 すると, 閉ループ極が指定領域に配置されない場合が生 ずる.したがって, 閉ループ系の極配置を考慮して MMP の最適化を行った場合, 平衡実現近似を直接用いてユー ラパラメータの低次元化を行うと, 指定領域に極配置を 行うことが不可能となる，そこで本論文では，極を指定 領域に保存しながらユーラパラメータを低次元化する近 
似手法を提案し, さらに本近似手法を用いて補償器を低 次元化した場合の $H_{\infty}$ ノルム条件保存のための十分条件 を導出する。

また, ユーラパラメータの中には極-零点相殺の影響に よって, 補償器の次数を下げるものが存在する.このよ うな場合, ユーラパラメータを低次元化すると, 補償器 の次数が下がらないことがしばしば起きる.これに対し て本論文では, $H_{\infty}$ 補償器の線形分数変換において起こ り得る極一零点相殺を考慮し, 最終的に得られる近似補償 器の次数が元の補償器の次数よりも低くなるための十分 条件を導出する.

このように本低次元化手法は内部安定性と閉ループ極 の存在領域を保存するという意味において閉ループ特性 を考慮し，また容易な計算によって $H_{\infty}$ ノルム条件を調 べることの可能な有用性のある手法である.

本論文の構成は以下のとおりである. 第 2 章において 本論文で用いる数式の説明と, 問題設定を行う. 第 3 章 では, 平衡実現近似手法を直接用いてユーラパラメータ を近似したとき， $H_{\infty}$ ノルム条件が保存されるための十 分条件を導出する. またさらに，モデルの極配置を保存 する低次元化手法を提案し, 本手法を用いてユーラパラ メータを近似したときの $H_{\infty}$ ノルム条件保存のための十 分条件を導出する. 第 4 章では, 極一零点相殺の影響を考 慮して, 近似補償器の次数が元の補償器の次数よりも低 次となるための十分条件を導出する. 第 5 章では数值例 を示し, 本手法の有効性を確認する. 第 6 章はまとめで ある。

\section{2. 準備と問題設定}

本縞ではつぎの記号を用いる.

$\operatorname{deg}(G)$ ： 伝達関数行列 $G(s)$ のマクミラン次数

$R H_{\infty}$ ： 安定でプロパーな有理関数の集合

$R H_{\infty}^{n}$ : マクミラン次数が $n$ で安定かつプロパーな 有理関数の集合

$\|\cdot\|_{\infty}: H_{\infty}$ ノルム また,

$$
\begin{aligned}
& \dot{\boldsymbol{x}}=A \boldsymbol{x}+B \boldsymbol{u} \\
& \boldsymbol{y}=C \boldsymbol{x}+D \boldsymbol{u}
\end{aligned}
$$

によって表わされるシステムの伝達関数行列 $G(s)$

$$
\begin{aligned}
G(s) & =\left[\begin{array}{ll}
G_{11} & G_{12} \\
G_{21} & G_{22}
\end{array}\right](s) \\
& =D+C(s I-A)^{-1} B
\end{aligned}
$$

を

$$
G(s)=\left[\begin{array}{l|l}
A & B \\
\hline C & D
\end{array}\right]
$$

で表わすことにする. 線形分数変換を

$$
F l(G(s), K(s))=G_{11}+G_{12} K\left(I-G_{22} K\right)^{-1} G_{21}(5)
$$
で表わす。

Fig. 1 の単一入力単一出力フィードバック系について 考える. $P(s), K(s)$ はそれぞれ制御対象, 補償器を表わ すプロパーな有理関数, $\Delta(s)$ は制御対象の加法的不確か さを表わす安定でプロパーな有理関数と仮定する.また， $\Delta(s)$ によ制御対象の不安定極の総数は変化しないと 仮定する。

一般に準最適 $H_{\infty}$ 制御問題はつぎのように評価関数の $H_{\infty}$ ノルムを 1 末満にする形で定式化される ${ }^{1), 4)}$.

[問題 1]

$$
\|W H\|_{\infty}<1
$$

を満たす全ての安定化補償器 $K(s)$ を求めよ.

本論文では (6) 式の条件を満足する安定化補償器を $H_{\infty}$ 補償器と呼ぶことにする.ここで, $W(s) \in R H_{\infty}$ は重み関 数である.また, $H(s)$ は閉ループ伝達関数であり, $P(s)$ と $K(s)$ の関数である.たとえば，重み関数 $W(s)$ を

$$
|\Delta(j \omega)| \leq|W(j \omega)|, \forall \omega
$$

を満たす安定かつプロパーな有理関数, $H(s)$ を

$$
H(s)=K(s)(1+P(s) K(s))^{-1}
$$

と選択すれば問題 1 はロバスト安定化問題となる，以下 では, 伝達関数の表記に扔いて $(s)$ を適宜省略すること にする。

つぎに, 問題 1 を YJB を介して MMP に変換する.ま ずつぎのように $P$ を安定な有理関数 $N, M \in R H_{\infty}$ で既 約分解する.

$$
P=N M^{-1}
$$

また, 適当な $X \in R H_{\infty}, Y \in R H_{\infty}$ に対して $N, M$ はべ ズー等式

$$
X N+Y M=1
$$

を満たす。

このとき, YJBにより, 制御対象を安定化する補償器 $K(s)$ は

$$
K(s)=F l\left(K_{0}, Q\right)
$$

で表わされる3) 5).ただし，

$$
K_{0}=\left[\begin{array}{cc}
Y^{-1} X & Y^{-1} \\
Y^{-1} & Y^{-1} N
\end{array}\right](s)
$$

$Q \in R H_{\infty}$ である.ここで, $Q$ は $R H_{\infty}$ のクラスに属する フリーパラメータであり， $Q$ が $R H_{\infty}$ のクラスに属して

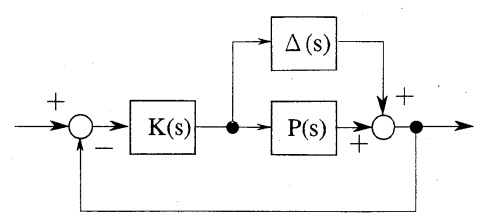

Fig. 1 Feedback system 


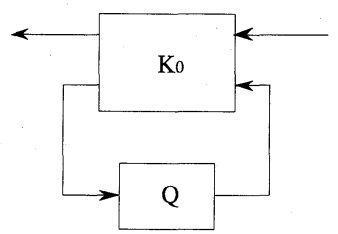

Fig. 2 Structure of stabilising controller

いれば $K$ は安定化補償器であることが保証されている. 安定化補償器 $K$ の構造を Fig. 2 に示す.

$$
\begin{aligned}
& K_{0}=\left[\begin{array}{c|cc}
A & B_{1} & B_{2} \\
\hline C_{1} & D_{11} & D_{12} \\
C_{2} & D_{21} & D_{22}
\end{array}\right] \\
& Q(s)=\left[\begin{array}{l|l}
A_{Q} & B_{Q} \\
\hline C_{Q} & D_{Q}
\end{array}\right]
\end{aligned}
$$

とすれば, 安定化補償器は

$$
K(s)=
$$

$$
\begin{aligned}
& {\left[\begin{array}{cc}
A+B_{2} D_{Q} E C_{2} & B_{2}\left(I+D_{Q} E D_{22}\right) C_{Q} \\
B_{Q} E C_{2} & A_{Q}+B_{Q} E D_{22} C_{Q} \\
\hline C_{1}+D_{12} D_{Q} E C_{2} & D_{12}\left(I+D_{Q} E D_{22}\right) C_{Q}
\end{array} \mid\right.} \\
& \left.\begin{array}{c}
B_{1}+B_{2} D_{Q} E D_{21} \\
\frac{B_{Q} E D_{21}}{D_{11}+D_{12} D_{Q} E D_{21}}
\end{array}\right]
\end{aligned}
$$

ただし，

$$
E=\left(I-D_{22} D_{Q}\right)^{-1}
$$

で表わされる。（15)式の実現は最小実現であるとは限ら ず, $K$ のマクミラン次数と, $K_{0}$ と $Q$ のマクミラン次数と の関係は

$$
\operatorname{deg}(K) \leq \operatorname{deg}\left(K_{0}\right)+\operatorname{deg}(Q)
$$

で表わされる。

この $K$ を用いて問題 1 を書き直すとつぎの MMP に 変換される。

[問題 2]

$$
\left\|T_{1}-Q T_{2}\right\|_{\infty}<1
$$

を満たす全ての $Q \in R H_{\infty}$ を求めよ。ただし， $T_{1}, T_{2} \in$ $R H_{\infty}$ である。

ここで, 問題 1 においては準最適 $H_{\infty}$ 制御問題が $(6)$ 式の $H_{\infty}$ ノルム条件と補償器 $K$ の内部安定条件により 構成されているのに対し，問題 2 では，(18)式のノルム 条件を満たす $R H_{\infty}$ のクラスに属する全ての $Q$ を求め る問題となっていることに注目する. 問題 2 において求 められる解を $Q^{*} \in R H_{\infty}$ とし, ユーラパラメータと呼ぶ ことにする。

さて, 閉ループ系の時間領域での特性は, $N, M, X, Y$ と $Q^{*}$ の極配置によって指定することが可能である。し かし, 閉ループ系の極配置を複素左半平面上において左
遠方にした場合，(18)式の条件を満たす $Q^{*}$ の次数は無 限大となることが示されており ${ }^{4)}$ ，一般に閉ループ系の 時間特性を考慮すると $Q^{*}$ の次数は高くなることが多く なる.また，Boyd らの提案手法により，凸最適化手法を 用いて閉ループ極を指定しつつ $Q^{*}$ の最適化を行うと, $Q^{*}$ の次数は增大することが知られている2). したがっ て，閉ループ系の時間特性を考慮すると，(17)式の関係 より, $H_{\infty}$ 補償器のマクミラン次数は高次となり, しばし ば補償器の低次元化が必要となる。しかしながら, 何ら かの低次元近似手法を用いて補償器を望みの次数に近似 したとしても, 高次の $H_{\infty}$ 補償器を直接近似することに よって得られる低次元化補償器が内部安定条件と ( 6 ) 式 のノルム条件の両方を満足するか調べなければならず, もしこれらの条件の片方でも満足されていなければ再度 低次元化をやり直し，これらを調べ直さなければならな い.

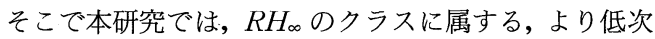
元の関数 $Q_{r}$ で $Q^{*}$ を近似することを考える。このよう に $Q^{*}$ を $R H_{\infty}$ のクラスに属する $Q_{r}$ で近似すれば，閉 ループ系の内部安定性は自動的に保証されるので，(18) 式のノルム条件を調べるだけで, 得られる低次元化補償 器が $H_{\infty}$ 補償器であるかが判別可能である.したがって, つぎの問題を考える.

[問題 3]

問題 2 亿おいて求めたユーラパラメータ $Q^{*} \in R H_{\infty}^{n}$ を, $Q_{r} \in R H_{\infty}^{r},(r<n)$ で近似する場合, $Q_{r}$ が

$$
\left\|T_{1}-Q_{r} T_{2}\right\|_{\infty}<1
$$

を満足するか，また $Q^{*}$ は(18)式の条件を満たしたまま 最高何次まで低次元化することができるか.

\section{3. ユーラパラメータ $Q^{*}$ の近似}

本章では，第 2 章で述べた考え方に従い，問題 2 で求 めたユーラパラメータ $Q^{*} \in R H_{\infty}^{n} を, Q_{r} \in R H_{\infty}^{r},(r<n)$ で近似することにより内部安定条件を満足し, $H_{\infty}$ 条件 を満たす低次元 $H_{\infty}$ 補償器を求めることを考える.また, 閉ループ系の極配置を考慮して $Q^{*}$ を求めた場合には, $Q^{*}$ の極の存在領域を保存しながら $Q^{*}$ を低次元化する 必要がある，そこで本章では，極の存在領域を保存する 低次元化手法を提案し， $H_{\infty}$ ノルム条件を保存するため の十分条件を導出する.

\section{1 平衡実現近似による $Q^{*}$ の近似とノルム条件}

前章で議論したように，閉ループ系の内部安定性を保 存するためには, ユーラパラメータ $Q^{*}$ を $R H_{\infty}$ のクラ スの中で低次元化することが必要である．そこで，シス テムモデルの安定性を保存したまま近似モデルを構成す ることの可能な平衡実現近似手法77,8),10)を用いる. 
平衡実現近似手法は，システムの可制御性可観測性に 着目し，システムのそれぞれのモードについて可制御性 と可観測性の度合いが等しくなるようにシステム全体の 等価変換(平衡化)を行った後, 可制御可観測性の低い モードを打ち切る低次完化手法である。したがって, シ ステムの入出力特性を保存しやすく, 漸近安定性も保存 する特徴を有している。

漸近安定で平衡実現された $n$ 状態システム

$$
Q^{*}=\left[\begin{array}{c|c}
A_{Q^{*}} & B_{Q^{*}} \\
\hline C_{Q^{*}} & D_{Q^{*}}
\end{array}\right]
$$

について考える。

$Q^{*}$ のハンケル特異值を

$$
\sigma_{1} \geq \sigma_{2} \geq \cdots \sigma_{r} \geq \sigma_{r+1} \geq \cdots \sigma_{n}
$$
とし,

$$
\begin{aligned}
& \Sigma=\left[\begin{array}{cc}
\Sigma_{1} & 0 \\
0 & \Sigma_{2}
\end{array}\right] \\
& \Sigma_{1}=\operatorname{diag}\left(\sigma_{1}, \sigma_{2}, \cdots, \sigma_{r}\right) \\
& \Sigma_{2}=\operatorname{diag}\left(\sigma_{r+1}, \sigma_{r+2}, \cdots, \sigma_{n}\right)
\end{aligned}
$$

を満足する。 $Q^{*}$ を $\Sigma$ と同様に

$$
\begin{aligned}
& A_{Q^{*}}=\left[\begin{array}{ll}
A_{Q 11} & A_{Q 12} \\
A_{Q 21} & A_{Q 22}
\end{array}\right], \quad B_{Q^{*}}=\left[\begin{array}{ll}
B_{Q 1} & B_{Q 2}
\end{array}\right] \\
& C_{Q^{*}}=\left[\begin{array}{l}
C_{Q 1} \\
C_{Q 2}
\end{array}\right]
\end{aligned}
$$

と分解すると，低次元化システム $Q_{r}$ は

$$
Q_{r}(s)=\left[\begin{array}{l|l}
A_{Q 11} & B_{Q 1} \\
\hline C_{Q 1} & D_{Q^{*}}
\end{array}\right]
$$

で与えられる。

平衡実現近似に関するつぎの補題が知られている。

\section{[補題 1 $]^{8)}$}

$Q^{*}$ を漸近安定，最小実現の $n$ 次元システムとする. 平衡実現近似によって得られる $r$ 次元低次元化システ ムを $Q_{r}(n>r)$ とするとき

1) $Q_{r}$ は漸近安定で, 最小実現

2) $\left\|Q^{*}-Q_{r}\right\|_{\infty} \leq 2$ trace $\Sigma_{2}$

が成り立つ。

以上の平衡実現近似手法の特徴を利用して， $H_{\infty}$ 補償 器の低次元化を考える. 以下では,

$$
\begin{aligned}
& \lambda^{*}=\left\|T_{1}-Q^{*} T_{2}\right\|_{\infty} \\
& \lambda_{r}=\left\|T_{1}-Q_{r} T_{2}\right\|_{\infty}
\end{aligned}
$$

とする。このとき，つぎの補題が成り立つ.

\section{[補題 2]}

$Q^{*}$ を $Q_{r}$ で近似したとき，

$$
\lambda_{r} \leq \lambda^{*}+\left\|Q^{*}-Q_{r}\right\|_{\infty}\left\|T_{2}\right\|_{\infty}
$$

が成立する。

(証明)

$$
\begin{aligned}
\lambda_{r} & =\left\|T_{1}-Q_{r} T_{2}\right\|_{\infty} \\
& =\left\|T_{1}-Q^{*} T_{2}+\left(Q^{*}-Q_{r}\right) T_{2}\right\|_{\infty} . \\
& \leq\left\|T_{1}-Q^{*} T_{2}\right\|_{\infty}+\left\|Q^{*}-Q_{r}\right\|_{\infty}\left\|T_{2}\right\|_{\infty}
\end{aligned}
$$

より,

が成立する。

補題 2 より, $\lambda^{*}<1$ が満足されていても $\lambda_{r}<1$ が満足 されない場合が存在する，このような場合，低次元化補 償器は $H_{\infty}$ 条件を満足しない. そこで, $H_{\infty}$ 条件を満たし たまま $Q^{*}$ はどれだけの次数を低次元化することができ るか，ということについてつぎの結果が得られる.

\section{《定理 1》}

平衡実現近似手法を用いて $Q^{*} \in R H_{\infty}^{n}$ を, $Q_{r} \in R H_{\infty}^{r}$, $(r<n)$ で近似した場合，つぎの条件

$$
\begin{aligned}
& \lambda^{*}+2 \operatorname{trace} \Sigma_{2}\left\|T_{2}\right\|_{\infty}<1 \\
& \text { ただし, } \Sigma_{2}=\operatorname{diag}\left(\sigma_{r+1}, \sigma_{r+2}, \cdots, \sigma_{n}\right)
\end{aligned}
$$

が成立すれば補償器

$$
\widehat{K}=F l\left(K_{0}, Q_{r}\right)
$$

は, $H_{\infty}$ 補償器である。

(証明)

補題 1 より

$$
\left\|Q^{*}-Q_{r}\right\|_{\infty} \leq 2 \text { trace } \Sigma_{2}
$$

が成り立つ.また, 補題 2 より

$$
\lambda_{r} \leq \lambda^{*}+\left\|Q^{*}-Q_{r}\right\|_{\infty}\left\|T_{2}\right\|_{\infty}
$$

が成り立つ。これらから

$$
\lambda_{r} \leq \lambda^{*}+2 \text { trace } \Sigma_{2}\left\|T_{2}\right\|_{\infty}
$$

が成立する。したがって，

$$
\lambda^{*}+2 \text { trace } \Sigma_{2}\left\|T_{2}\right\|_{\infty}<1
$$

が成り立てば

$$
\lambda_{r}<1
$$

となる。また, $Q_{r} \in R H_{\infty}$ であることから, $\hat{K}$ は $H_{\infty}$ 補償 器である.

この結果の重要なポイントは, 平衡実現近似手法に よって直接近似されるューラパラメータ $Q^{*}$ のハンケル 特異值を用いることにより, 近似した補償器の $H_{\infty}$ 条件 を逐一補償器を計算せずに調べることが可能であると同 時に, ハンケル特異值の和を計算するのみで, $H_{\infty}$ 条件を 満たしたままごれだけ $Q^{*}$ の次数を低減できるかについ て知ることが可能な点にある。

\section{2 極配置を考慮した $Q^{*}$ の近似}

閉ループ系の極配置は, 過渡応答特性と密接な関係が ある。したがって，ロバスト安定化などの仕様と共に閉 ループ極の指定を行うことは十分意義がある. $N, M, X$, $Y$ をそれぞれ指定領域内に極が存在するように求め,さ 
らに指定領域内に極が存在するように $Q$ を最適化すれ ば，閉ループ極は指定領域内に配置される。平衡実現近 似手法は，前節で述べたように，システムモデルの漸近 安定性と入出力関係を保存する特徵を有する近似手法で ある。しかしながら，近似した際にシステムモデルの極 の存在領域は保存されない場合があり，本論文で提案す る補償器の低次元化手法において平衡実現近似手法を直 接用いた場合，閉ループ極は指定した領域内に保存され ない.そこで本節では, ユーラパラメータ $Q^{*}$ の極を左半 面上の円領域内に保存しながら $Q^{*}$ を近似する低次元化 手法を提案する。ささらに本手法を用いてユーラパラメー 夕 $Q^{*}$ を近似したときの $H_{\infty}$ ノルム条件の保存について の結果を述べる.

ここで，つぎの記号を定義する.

$$
C:=\{s|| s+\alpha \mid=\beta, \operatorname{Re} s<0\}
$$$$
D:=\{s|| s+\alpha \mid<\beta \text {, Re } s<0\}
$$

ただし， $\alpha, \beta$ は実数， $\alpha>\beta>0$ とする

複素領域内の左半面上の, 中心が $(-\alpha, 0)$, 半径が $\beta$ の 円領域 $D$ (Fig. 3) は，アフィン変換

$$
\nu=\frac{s+\alpha}{\beta}
$$

と, 双一次変換

$$
\tilde{s}=\frac{\nu-1}{\nu+1}
$$

により複素数領域の左半平面 (Fig. 4) に変換される.こ のとき, 円領域 $D$ から左半面への変換は

$$
\tilde{s}=\frac{s+\alpha-\beta}{s+\alpha+\beta}
$$

で表わされる，この変換を用いて $s$-平面上の円領域 $D$ 内のみに極をもつユーラパラメータ $Q^{*}(s)$ を左半面の みに極をもつ伝達関数に書き直すと

$$
Q *\left(\frac{(-\alpha-\beta) \tilde{s}+\alpha-\beta}{\widetilde{s}-1}\right)
$$

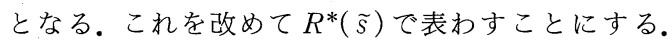
$R^{*}(\widetilde{S})$ は右半平面に扔いて正則であり, 漸近安定な伝達 関数である。

つぎに，漸近安定な伝達関数 $R^{*}$ を平衡実現近似手法

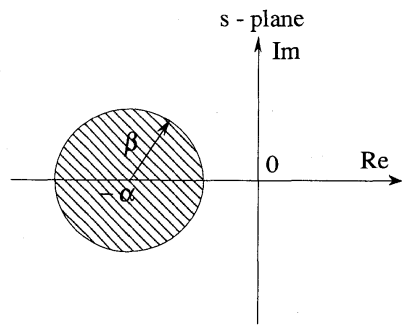

Fig. 3 Disk domain
を用いて漸近安定な伝達関数で近似し, 近似したこの伝 達関数をアフィン変換と双一次変換の逆変換により, 円 領域 $D$ 内のみに極を有する伝達関数に変換する。このよ うにして, 左半面上の円領域 $D$ 内に極をもつ伝達関数 を, 同じ領域内のみに極を有する低次元の伝達関数に よって近似することを考える。このとき，つぎの補題が 成立する。

\section{[補題 3]}

$R^{*}(\widetilde{s})$ は右半面で正則であると仮定する. $R^{*}(\widetilde{s})$ を 平衡実現近似し，光れを $\hat{R}(\tilde{s})$ とする。このとき，

$$
\left\|R^{*}(\tilde{s})-\hat{R}(\tilde{s})\right\|_{\infty}<a
$$

ならば

$$
\left\|Q^{*}(s)-\hat{Q}(s)\right\|_{\infty}<a
$$

が成立する。ただし，

$$
\widehat{Q}(s)=\hat{R}\left(\frac{s+\alpha-\beta}{s+\alpha+\beta}\right)
$$

とする。

(証明)

$$
\begin{aligned}
& E(\widetilde{s})=R^{*}(\tilde{s})-\hat{R}(\widetilde{s}) \\
& H(s)=Q^{*}(s)-\widehat{Q}(s)
\end{aligned}
$$

とする.このとき, $Q^{*}(s), \hat{Q}(s)$ は円領域 $D$ 内のみに極 をもつことから， $H(s)$ は円領域 $D$ の外側において正則 である.したがって最大值の原理から, $H(s)$ の円周 $C$ 上 に颃ける最大值は，虚軸上での最大值よりも大きい。す なわち，

$$
\sup _{c}\{H(s)\}>\sup _{\omega}\{H(j \omega)\}
$$

が成立する。

(48) 式の変換は, 円周 $C$ 上の值を虚軸上の值に写像す る変換であり, $E(\widetilde{s})$ の $\tilde{s}$ 平面上における虚軸上での上 限は $H(s)$ の $s$ 平面上に扔ける円周 $C$ 上での上限に一 致する.すなわち，

$$
\sup _{\omega}\{E(j \omega)\}=\sup _{c}\{H(s)\}
$$

が成立する。また， $R^{*}(\widetilde{s}) \in R H_{\infty}, \hat{R}(\widetilde{s}) \in R H_{\infty}$ である ことから, $E(\widetilde{s})$ は右半面において正則であり, $E(\tilde{s})$ の $H_{\infty}$ ノルムは虚軸上での最大值に一致する。したがって,

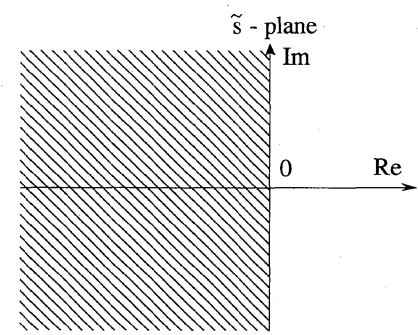

Fig. 4. Left half plane 


$$
\|E(\tilde{s})\|_{\infty}=\sup _{c}\{H(s)\}
$$

である.（57)式より

$$
\|E(\widetilde{s})\|_{\infty}<a
$$

が成立すれば

$$
\sup _{c}\{H(s)\}<a
$$

となる.よって，(55)式と（59)式より

$$
\sup _{\omega}\{H(j \omega)\}=\|H(s)\|_{\infty}
$$$$
<a
$$

が成立する.

補題 1 と補題 3 よりただちにつぎの定理が導かれる. 《定理 2》

平衡実現近似手法を用いて $R^{*} \in R H_{\infty}^{n}$ を $\hat{R} \in R H_{\infty}^{r}(r$ $\leq n)$ で近似する. $R^{*}$ の近似されたモードのハンケル特 異值を $\sigma_{R, r+1}, \sigma_{R, r+2}, \cdots, \sigma_{R, n}$ とする，このとき，

$$
\begin{aligned}
& \lambda^{*}+2 \operatorname{trace} \sum_{R 2}\left\|T_{2}\right\|_{\infty} \leq 1 \\
& \text { ただし, } \sum_{R 2}=\operatorname{diag}\left(\sigma_{R, r+1}, \sigma_{R, r+2}, \cdots, \sigma_{R, n}\right) \\
& \text { が成立すれば, 補償器 } \\
& \widehat{K}=F l\left(K_{0}, \widehat{Q}\right)
\end{aligned}
$$

は $H_{\infty}$ 補償器である.また,このときの閉ループ極は円領 域 $D$ 内のみに存在する。

（証明） 補題 1 より

$$
\left\|R^{*}-\hat{R}\right\|_{\infty} \leq 2 \text { trace } \sum_{R 2}
$$

が成立する。したがって補題 3 より

$$
\left\|Q^{*}-\hat{Q}\right\|_{\infty} \leq 2 \text { trace } \sum_{R 2}
$$

が成立する。また，

$$
\begin{aligned}
& \left\|T_{1}-\bar{Q} T_{2}\right\|_{\infty}=\left\|T_{1}-Q^{*} T_{2}+\left(Q^{*}-\hat{Q}\right) T_{2}\right\|_{\infty} \\
& \quad \leq\left\|T_{1}-Q^{*} T_{2}\right\|_{\infty}+\left\|Q^{*}-\hat{Q}\right\|_{\infty}\left\|T_{2}\right\|_{\infty} \\
& \quad=\lambda^{*}+\left\|Q^{*}-\hat{Q}\right\|_{\infty}\left\|T_{2}\right\|_{\infty} \\
& \quad<\lambda^{*}+2 \operatorname{trace} \Sigma_{R 2}\left\|T_{2}\right\|_{\infty}
\end{aligned}
$$

となり，

$$
\lambda^{*}+2 \text { trace } \Sigma_{R 2}\left\|T_{2}\right\|_{\infty} \leq 1
$$

が成立すれば

$$
\begin{gathered}
\left\|T_{1}-\widehat{Q} T_{2}\right\|_{\infty}<1 \\
\text { であり, } \widehat{Q} \in R H_{\infty} \text { より } \\
\widehat{K}=F l\left(K_{0}, \widehat{Q}\right)
\end{gathered}
$$

は $H_{\infty}$ 補償器である。 また, $N, M, X, Y, Q$ の極は円領 域 $D$ 内のみに存在することから, それらの積と和で表わ される閉ループ伝達関数は, 円領域 $D$ 内のみに極をも つ.

\section{4. $H_{\infty}$ 補償器の低次元化}

前章では，ユーラパラメータ $Q^{*}$ を低次元化すること によって得られる補償器が $H_{\infty}$ 条件を満足する条件を導 出した.しかしながら， $Q^{*}$ を低次元化することによって 得られる $H_{\infty}$ 補償器の近似モデルが, 元の $H_{\infty}$ 補償器の
次数よりも実際には低次とならない場合が存在する。こ れは, 元の $H_{\infty}$ 補償器において, $K_{0}$ と $Q^{*}$ との間で極-零 点相殺が起こり, 補償器全体のマクミラン次数が $K_{0}$ と $Q^{*}$ のマクミラン次数の和より小さくなる場合に起こり 得る. 本章では, 補償器の内部において起こり得る極-零 点相殺について考察し，ユーラパラメータを低次元化す ることによって近似された $H_{\infty}$ 補償器が, 元の $H_{\infty}$ 補償 器よりも低次元となるための条件を導出する.

以下では $Q_{r}(s)$ と $\widehat{Q}(s)$ を区別せず, $Q_{r}(s)$ で表わすこ とにする。 $Q^{*}(s)$ の実現を

$$
Q^{*}(s)=\left[\begin{array}{c|c}
A_{Q^{*}} & B_{Q^{*}} \\
\hline C_{Q^{*}} & D_{Q^{*}}
\end{array}\right]
$$

とすると, $H_{\infty}$ 補償器は

$$
\begin{aligned}
K= & F l\left(K_{0}, Q^{*}\right) \\
= & {\left[\begin{array}{cc}
A+B_{2} D_{Q^{*}} F C_{2} & B_{2}\left(I+D_{Q^{*}} F D_{22}\right) C_{Q^{*}} \\
\frac{B_{Q^{*}} F C_{2}}{C_{1}+D_{12} D_{Q^{*}} F C_{2}} & A_{Q^{*}}+B_{Q^{*}} F D_{22} C_{Q^{*}} \\
& B_{1}+B_{2} D_{Q^{*}} F D_{21} \\
& \frac{B_{Q^{*}} F D_{21}}{D_{11}+D_{12} D_{Q^{*}} F D_{21}}
\end{array}\right] }
\end{aligned}
$$

ただし, $F=\left(I-D_{22} D_{Q^{*}}\right)^{-1}$

で表わされる。（71）式は最小実現とは限らず，不可制御 モードまたは不可観測モードが存在する場合には極-零 点相殺が起こり, $H_{\infty}$ 補償器 $K$ のマクミラン次数は低下 する.したがって,

$$
\operatorname{deg}(K) \leq \operatorname{deg}\left(K_{0}\right)+\operatorname{deg}\left(Q^{*}\right)
$$

という関係が成立する。

$$
\begin{gathered}
\text { 一方, } \hat{K}=F l\left(K_{0}, Q_{r}\right) \text { についても, } \\
\operatorname{deg}(\widehat{K}) \leq \operatorname{deg}\left(K_{0}\right)+\operatorname{deg}\left(Q_{r}\right)
\end{gathered}
$$

という関係が成立する.したがって, 極一零点相殺の影響 により, 近似補償器の次数が元の補償器の次数よりも大 きくなることがある.

ここで,

$$
K_{0}=\left[\begin{array}{ll}
K_{11} & K_{12} \\
K_{21} & K_{22}
\end{array}\right](s)
$$

としたとき, $F l\left(K_{0}, Q\right)$ の不可制御モード, 不可観測モー ドについてはつぎの結果が示されている.

\section{$[\text { 補題 4 }]^{7)}$}

$F l\left(K_{0}, Q\right)$ の全ての不可観測モードは, $K_{12}$ の零点, ま た, $F l\left(K_{0}, Q\right)$ の全ての不可制御モードは $K_{21}$ の零点で ある。

(証明) 文献 9)参照.

$K_{12}$ の零点と $K_{21}$ の零点の総数を $T Z$ とすると, つぎ の結果が得られる.

《定理 3》

$$
\operatorname{deg}\left\{F l\left(K_{0}, Q^{*}\right)\right\}>\operatorname{deg}\left\{F l\left(K_{0}, Q_{r}\right)\right\}
$$


成り立つための十分条件は,

$\left\{Q^{*}\right.$ の低次元化数 $\}>\{T Z\}$

である。

(証明)

$\left\{Q^{*}\right.$ の低次元化数 $\}>\{T Z\}$

すなわち

$$
\operatorname{deg}\left(Q^{*}\right)-\operatorname{deg}\left(Q_{r}\right)>T Z
$$

が成り立つと仮定する。補題 4 より $F l\left(K_{0}, Q^{*}\right)$ の内部に おける極一零点相殺は $F l\left(K_{0}, Q^{*}\right)$ の不可観測または不可 制御モードにおいて起こりうる.したがって, $\operatorname{deg}\left\{F l\left(K_{0}, Q^{*}\right)\right\} \geq \operatorname{deg}\left(K_{0}\right)+\operatorname{deg}\left(Q^{*}\right)-T Z$ という関係が成り立つ。（78）式，(79)式より $\operatorname{deg}\left\{F l\left(K_{0}, Q^{*}\right)\right\}>\operatorname{deg}\left(K_{0}\right)+\operatorname{deg}\left(Q_{r}\right)$ が成り立つ。また， $F l\left(K_{0}, Q_{r}\right)$ においては $\operatorname{deg}\left\{F l\left(K_{0}, Q_{r}\right)\right\} \leq \operatorname{deg}\left(K_{0}\right)+\operatorname{deg}\left(Q_{r}\right)$ が成り立つ。したがって，(80)式と(81)式より

$$
\operatorname{deg}\left\{F l\left(K_{0}, Q_{r}\right)\right\}<\operatorname{deg}\left\{F l\left(K_{0}, Q^{*}\right)\right\}
$$

（77）の条件式において，右辺は一定値であり，左辺は あらかじめ設定するユーラパラメータの次元が大きいほ ど大きくなる。したがってユーラパラメータの次元をあ らかじめ大きく設定してパラメータの最適化を行い, 求 められたユーラパラメータの近似を行う $H_{\infty}$ 制御問題の 数值的解法を用いる上で本条件は有用となる．以上の結 果より，Q*近似することによって得られる $H_{\infty}$ 補償 器が, 低次元化補償器であるための条件が導出された。

\section{5. 数 值 例}

本数値例では，前章までに得られた結果の有効性を確 認するために, 制御対象 $P(s)$, 加法的不確かさ $\Delta(s)$ がそ れぞれ

$$
\begin{aligned}
& P(s)=\frac{s-2}{(s-1)(s+1)} \\
& \Delta(s)=0.1 \frac{3 s+1}{s+1}
\end{aligned}
$$

で与えられる Fig. 1のフィードバック系のロバスト安 定化補償器の低次元化について考える，閉ループ極を考 慮し, 制御対象の伝達関数を安定かつプロパーな有理関 数上で次式のように既約分解する.

$$
\begin{gathered}
P(s)=N(s) M^{-1}(s) \\
N(s)=\frac{s-2}{(s+2)(s+3)} \\
M(s)=\frac{(s-1)(s+1)}{(s+2)(s+3)} \\
\text { ベズー等式 } \\
X(s) N(s)+Y(s) M(s)=1
\end{gathered}
$$

を満たす $X(s), Y(s)$ を

$$
\begin{aligned}
& X(s)=\frac{-176 s-184}{(s+4)(s+5)} \\
& Y(s)=\frac{s^{2}+14 s+248}{(s+4)(s+5)}
\end{aligned}
$$

と求める.（7)式を佩たすように重み関数 $W(s)$ を

$$
W(s)=\Delta(s)
$$

とすると，ロバスト安定化問題は

$$
\|W H\|_{\infty}<1
$$

ただし， $H(s)=M(s) X(s)+Q(s) M^{2}(s)$ とする を満たす $Q(s)$ を $R H_{\infty}$ のクラスから求める問題に帰着 される. 本問題において，(83) 式を満たす解 $Q^{*}(s)$ が得 られたときロバスト安定化補償器 $K^{*}(s)$ は,

$$
K^{*}(s)=F l\left(K_{0}(s), Q^{*}(s)\right)
$$

で与えられる。ここで，

$$
\begin{aligned}
K_{0}(s) & =\left[\begin{array}{cc}
K_{11}(s) & K_{12}(s) \\
K_{21}(s) & K_{22}(s)
\end{array}\right] \\
& =\left[\begin{array}{cc}
Y^{-1}(s) X(s) & Y^{-1}(s) \\
Y^{-1}(s) & Y^{-1}(s) N(s)
\end{array}\right]
\end{aligned}
$$

である、さて， $Q^{*}(s)$ が

$$
Q^{*}(s)=2.67 \frac{\prod_{i=1}^{17}\left(s-z_{i}\right)}{\prod_{i=1}^{17}\left(s-p_{i}\right)}
$$

として求まったとする。 $z_{i}$ は零点, $p_{i}$ は極を表わす. $Q^{*}$ の極配置を Fig. 5 に示す。このとき $K^{*}(s)$ は (84) 式に よって求められ, マクミラン次数は 19 次, 評価関数の值 は

$$
\lambda^{*}=0.802
$$

である，そこでこのような $H_{\infty}$ 補償器を閉ループ極の存 在範囲を指定しつつ低次元化することを考える，極の指 定領域を,左半面上において中心 $(-100,0)$, 半径 99.5 の 円の内部とする。

$$
\begin{aligned}
& T_{1}(s)=W(s) M(s) X(s) \\
& T_{2}(s)=-W(s) M^{2}(s)
\end{aligned}
$$

とすると，

$$
\left\|T_{2}(s)\right\|_{\infty}=0.3
$$

である. (48)式の変換により $R^{*}(s)$ を求める. $R^{*}(s)$ の ハンケル特異值を求め, 定理 2 の結果を適用すると,

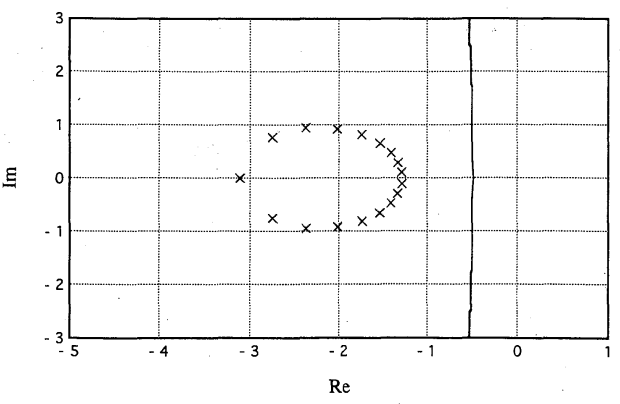

Fig. 5 Pole position of $Q^{*}(s)$ 


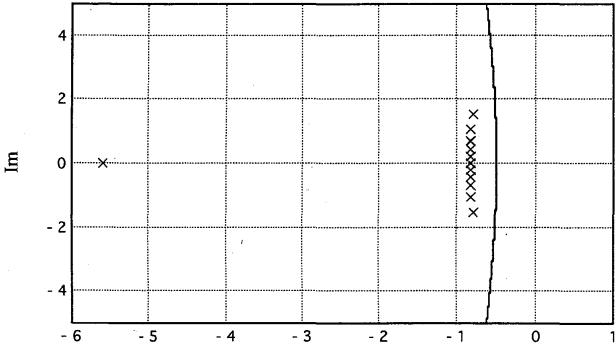

$\mathrm{Re}$

Fig. 6 Pole plot I

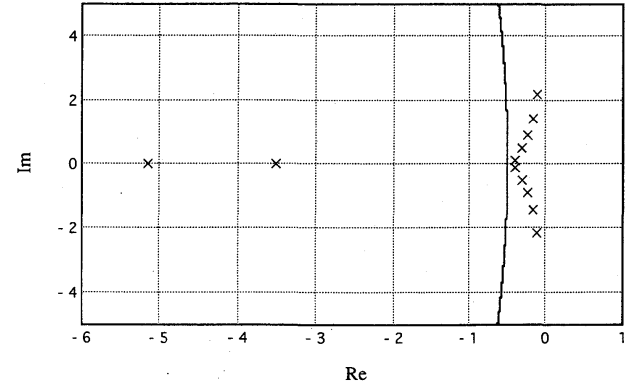

Fig. 7 Pole plot II

Table 1 A summary of $\operatorname{deg}\left(Q_{r}\right), \lambda^{*}+2 \operatorname{trace} \sum_{\mathrm{R} 2}\left\|T_{2}\right\|_{\infty}, \lambda$ and McMillan degree of controllers

\begin{tabular}{l|c|c|c}
\hline \hline $\operatorname{deg}\left(Q_{r}\right)$ & $\lambda^{*}+2 \operatorname{trace} \sum_{\mathrm{R} 2}\left\|T_{2}\right\|_{\infty}$ & $\lambda$ & $\operatorname{deg}\left\{F l\left(K_{0}, Q_{r}\right)\right\}$ \\
\hline $17\left(Q^{*}\right)$ & - & 0.802 & $20(19)$ \\
\hline 16 & 0.803 & 0.802 & $20(18)$ \\
\hline 15 & 0.805 & 0.802 & $19(17)$ \\
\hline 14 & 0.814 & 0.802 & $18(16)$ \\
\hline 13 & 0.839 & 0.804 & $17(15)$ \\
\hline 12 & 0.965 & 0.807 & $16(14)$ \\
\hline 11 & 1.21 & 0.826 & $15(13)$ \\
\hline 10 & 2.47 & 1.09 & $13(12)$ \\
\hline
\end{tabular}

Table 1 に示すように $Q^{*}(s)$ は極を指定領域に保存し, さらにロバスト安定条件を満たしたままマクミラン次数 を 5 次低減することが可能であることがわかる.Fig. 6 に $Q^{*} 5$ 次元低次元化して得られた $Q_{12}$ の極を示す. これより, 指定領域内に極が配置されていることがわか る.一方, 平衡実現近似手法を直接用いて $Q^{*}$ を 5 次低次 元化した場合の $Q_{12}$ の極を Fig. 7 に示す. なお, Fig. 5, Fig. 6, Fig. 7 中の曲線は極の指定領域を表わす円であ る.ここで，極の指定領域の設定方法については現在の ところ解析的な指針はなく，本数値例では思考錯誤によ り設定した.つぎに，(85)式より $K_{12}(s), K_{21}(s)$ の零点の 総数 $T Z$ は, 4 であり, 定理 3 の結果を用いると, 近似さ れた $H_{\infty}$ 補償器は, 元の補償器よりも低次元となること がわかる. Table 1 に $Q^{*}$ を低次元化した $Q_{r}$ のマクミラ ン次数と評価関数の值 $\lambda$, 補償器のマクミラン次数の関 係を示す.補償器の次数は計算器を用いて計算した值と, 理論値(()内)を示した。ここで理論值は, $F l\left(K_{0}, Q_{r}\right)$ に おいて極一零点相殺が起こらない場合のマクミラン次数 とした。なお，本数值例の数值計算には MATLAB を用 いた.

\section{6. おわりに}

本論文では，ューラパラメータを低次元化することに より, $H_{\infty}$ 補償器を間接的に低次元化する $H_{\infty}$ 補償器低
次元化手法を提案した，近似手法としては，システムモ デルの極の存在領域を保存しながら近似することの可能 な手法を提案し, これを用いた。本低次元化手法の特徵 は

1)内部安定性を保存する.

2)閉ループ極の存在領域を保存する.

3) 低次元化した補償器の $H_{\infty}$ ノルム条件を, 低次元化し た補償器を逐一求めることなく $Q^{*}$ のハンケル特異值 を求めることによって，容易に調べることが可能. といったことがあげられる. また, $H_{\infty}$ 補償器の線形分数 変換において起こり得る極一零点相殺を考慮し,最終的に 得られる近似補償器の次数が元の補償器の次数よりも低 次となるための十分条件を導出した. 以上のとおり本提 案手法は, 内部安定性と閉ループ極の存在領域を保存す るという意味において閉ループ特性を考慮した $H_{\infty}$ 補償 器の従来にない新しい低次元化手法である.

\section{参 考 文 献}

1) S. P. Boyd and C. H. Barratt : Linear Controller Design, Prentice-Hall (1991)

2）小原，杉江：凸最適化を用いた制御系設計，システム/制 御/情報, 38-3, 139/146（1994）

3）前田，杉江：アドバンスト制御のためのシステム制御理 論, 朝倉書店 (1990)

4) M. Vidyasagar: Control System Synthesis, MIT Press, Boston (1985) 
5) B. A. Francis: A Course in $H_{\infty}$ Control Theory, Springer-Verlag (1987)

6）前田, 児玉,鄭：安定領域を指定した $H_{\infty}$ 制御, 計測自動制 御学会論文集, 28-10, 1194/1200 (1992)

7) K. Glover : All Hankel-norm Approximations of Linear Multivariable Systems and Their $L_{\infty}$-error Bounds, Int J. Control, 39-6, 1115/1193 (1984)

8) D. Mustafa and K. Glover: Controller Reduction by $H_{\infty}$-Balanced Truncation, IEEE Trans., AC-36-6, 668/ 682 (1991)

9) D. J. N. Limebeer, Y.S. Hung: An Analysis of The Pole-Zero Cancellations in $H_{\infty}$-Optimal Control Problems of The First Kind, SIAM J. Control And Optimization, 25-6, 1457/1493 (1987)

10）大日方五郎：平衡実現, ハンケルノルム及び連分数展開を 用いた制御系の低次元化，システム/制御/情報, 34-9, 508/ 514 (1990)

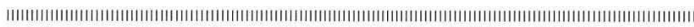

\section{[著 者 紹 介]}

渡 辺隆 男 (正会員)

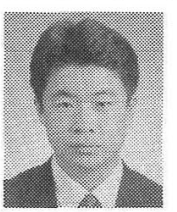

1994 年, 東京都立大学大学院工学研究科 電気工学専攻修士課程修了. 同年同大学工 学部助手, 現在に至る。ロバスト制御の研 究に従事。電気学会の会員.
安 田 恵一郎 (正会員)

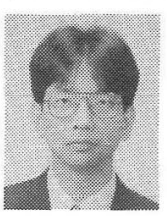

1989 年, 北海道大学大学院工学研究科電 気工学専攻博士課程修了。同年東京都立大 学工学部助手, 91 年同大学工学部助教授と なり, 現在に至る。主として，大規模シス テムの計画・運用・制御に関する研究に従 事(工学博士)。電気学会, システム制御情 報学会, OR 学会などの会員.

\section{横 山 隆 - (正会員)}

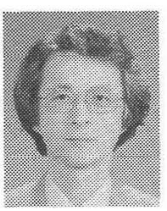

1973 年, 早稲田大学大学院理工学研究科 電気工学専攻博士課程修了. 74 年(株)三菱 総合研究所入社, 78 年東京都立大学工学部 助教授, 89 年同大学工学部教授となり, 現 在に至る。主として, 大規模システムの計 画・運用・制御，ディジタルシステム制御， エキスパートシステム, ファジィ理論応用 佀関する研究に従事(工学博士)。電気学会, システム制御情報学会などの会員.

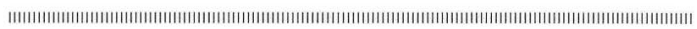

